\title{
CONFESSING NICEA TODAY? CRITICAL QUESTIONS FROM A SOUTH AFRICAN PERSPECTIVE
}

\author{
Piet Naude \\ University of Port Elizabeth
}

\begin{abstract}
After a short introduction on the World Council of Churches (WCC) project relating to a common expression of our apostolic faith, six questions are raised from a South African perspective. These questions serve as polemical pointers to argue that the common confession- project has limited value to address both issues of church unification and the construction of a public theology in South Africa.
\end{abstract}

\section{Introduction}

In terms of its constitution, the World Council of Churches aims “...to call the churches to the goal of visible unity in one faith and in one eucharistic fellowship expressed in worship and in common life in Christ, and to advance towards that unity in order that the world may believe." (Constitution III.1) This is echoed in the aim of Faith and Order namely "to proclaim the oneness of the Church of Jesus Christ and to call the churches to the goal of visible unity in one faith and one eucharistic fellowship, expressed in worship and in common life in Christ, in order that the world may believe" (Bylaws 3.1).

The question of "visible unity in one eucharistic fellowship" was addressed in the wellknown Baptism-Eucharist-Ministry-project (BEM) that culminated in the 1982 Lima declaration and its accompanying liturgy. The issue of "visible unity in one faith" relates to the study project Towards the common expression of the apostolic faith, officially launched in Lima, and taken further in subsequent conferences to produce a study guide on the explication, recognition and common confession of the one faith as expressed in the Nicene-Constantinopolitan Creed (NC). The study was published in 1991 by the WCC as a Faith and Order document (paper 153) entitled Confessing the one faith. Whereas BEM could be construed as the "order" side of the search for unity, this initiative relates to the "faith" side of a visibly united church (Neuner 1997:163).

\section{The choice for Nicea ${ }^{1}$}

The choice for NC as expression of the apostolic faith is explained in the Lima document which states that "...it is impossible to disregard the special place of the Nicene Creed. It is the one common creed which is most universally ${ }^{2}$ accepted, as formulation of the apostolic faith by churches in all parts of the world, where it primarily serves as the confession of faith in the eucharistic liturgy" (Link 1985: 216-217). This relates to the so-called double consensus which accompanied the self-understanding of the early Councils already expressed in the 5th century, namely consensio atiquitatis et universitatis, or vertical and

1. Due to historical reasons, the full title is the Nicene-Constantinopolitan Creed, abbreviated for our purposes as $\mathrm{NC}$.

2. NC was accepted by the Eastern church as baptismal creed since 451. It became part of the Western church's Eucharist liturgy since the Synod of Toledo (Spain) in 589 and became part of the Lutheran, Anglican and Reformed Churches' heritage even after new confessional documents were accepted. In practice though, the Apostolicum occupies a far more prominent place in Reformed liturgies than Nicea (Link 1998:34-35). 
horizontal consensus (see Sieben 1979: 515). It historical significance, universal acceptance and liturgical use confirms that NC expresses "the fundamentals of the apostolic faith" (Confessing the one faith 1991:4) as one of the few threads which can still hold a divided Christian church together (Kelly 1972: 208).

The question arises how South African churches and theologians should view the One Faith-process. Following a polemic approach, I wish to state a few questions- some general, and others more related to our context - regarding the project in our contemporary situation. As a member of the Dutch Reformed family of churches ${ }^{3}$, my remarks are strongly influenced by the situation in that specific family.

\section{Questions from a SA perspective}

3.1 Does the NC as a doctrinal formulation of orthodoxy have more than limited value in contributing to visible church unity today?

No one can doubt the historical and theological importance of $\mathrm{NC}$ as the first formal expression of faith assigned with the authority of "orthodoxy" In his illuminating discussion of confessions as communicative acts of faith, Edmund Arens divides the history of confessions in the church as follows: The Sitz im Leben of the earliest confessions was the liturgy, i.e. baptism, confession of faith and confession of sin. From Nicea onward, a new genre of "Lehrendes Bekennen"", linked to synods and councils, is established. Arens sees the confessions (Bekenntnisschriften) of the Reformation period with their strong "teaching" character in the same light. This is then followed by "Situatives Bekennen", (a somewhat unfortunate term) like Barmen and other declarations of the 20th century.

The question is whether the genre of a formal faith confession as such is helpful in establishing greater church unity - apart from the question whether Nicea specifically can / should play such a role.

One thinks of the many non-creedal or more independent type churches that - rightly or wrongly - consider confessional statements as unwarranted intrusions between the Scriptural Word and the believer (Horgan 1988:64). Or of churches that harbour a much more individualist and prophetic understanding of the Holy Spirit. Or of groups such as the many African Independent Churches that operate in an oral context where the inscripturation of faith is in principle not a practical option, and may indeed be experienced as alienating. The interesting point is that empirical data about church demography in SA (see Hendricks 1996) show that it is precisely these churches - and not the historical mainline ones - that show growth. And they are not part of the broader ecumenical movement which are seen by some as dominated by the concerns of the older churches for whom the early church and its doctrinal decisions carry a normativity not easily transferred to younger churches (see Neuner 1997:165).

In SA where "creedal" churches do in fact share a common confession of NC, the complexities of the situation (our political and church histories, our diverse cultures and languages, our socio-economic divides), make church unity a slow and painful process,

3. See the recent very informative Scriptura- edition (September 2001) dedicated to a discussion of the DRC in the transition to democracy in South Africa.

4. "War auch bisher das Moment der rechten Lehre schon im Bekennen praesent..., kam darueber hinaus mit der regula fidei bereits der Zusammenhang von Bekennen und rechter Lehre zum Ausdruck, so wird mit dem Konzil von Nizaea das Bekenntnis selbst zum Lehrbekenntnis” (Arens 1989:265).

5. This is a somewhat unfortunate term as it unwittingly implies that the earlier creeds, and confessions from the time of the Reformation, were not "situation bound"! 
because the divisions are much more than creedal confession (although not unrelated to issues of faith and confession $)^{6}$. The DRC-family, which has had six shared symbols of faith - including NC - over a period of more than a hundred years, is a case in point. Even without the complication of the 1986 Confession of Belhar, a common confession of the $\mathrm{NC}$ has been and is - to say the least - not of any help in fostering greater unity.

\subsection{Is the language (thought form) of - as well as issues addressed by - Nicea helpful in the process of church unification?}

One should obviously read NC in its context and see its great significance in what it set out to achieve in the fourth century church. But the valid question asked by Robert Hood in his book Must God remain Greek? Afro-cultures and God-talk needs to be echoed in a South African context. The agenda to talk about God, Christ and the Spirit from the NCassumptions "...threatens the survival and integrity of Christian identity in this world of many and varied cultures" (Hood 1990, xi). It excludes or make the intellectual contribution of African and other cultures very difficult, and represents a form of ecclesial neo-colonialism by Eurocentric and American churches that control the ecumenical movement (see Hood 1990:247-248 and Stanley Harakas' reply in Harakas 1991).

The same could obviously be said about the Ancient Near Eastern (OT) or GraecoRoman (NT) context of the Bible. There is, however, a clear distinction between the Bible as canon and norma normans of the church and subsequent efforts to express the Christian faith. For the first everyone everywhere should show great hermeneutical patience; for the second one should be far more open to ongoing, varied expressions of faith in different contexts and different thought forms, than to attempt to take everyone back to the fourth century. "The confessional heritages may have a continuing life in the united Church, as long as they nourish the witness of the local church and do not diminish its capacity for responding to the needs of the people whom it called to serve" (From: A fellowship of local churches truly united 1976, as printed in Gassmann 1993:74).

Apart from the "ethnocentric philosophical ideas" from the fourth century (Hood), one could also ask questions about the issues addressed by NC. No responsible theologian can underestimate the intricate and delicate doctrinal decisions represented by creeds and confessions that became part of the church's precious heritage. Nicea itself was - in the context of the fourth century - described as a wonder (Sieben 1979: 514). But it is quite another issue to launch a project by which those formulations and decisions - now almost an unconscious part of our tradition - are put before the whole church as the apostolic faith for today. Yes, it can and must - like any classic document - be explicated for today as in the study document. But, as I will show below, this has its own limitations that depend on who does the interpretation work ${ }^{7}$.

We in SA who now live from the fresh and contextual language of the Belhar confession and who are faced with urgent life-threatening issues not addressed in $\mathrm{NC}$, would rather opt for a reclaiming of a specific Scriptural passage/passages or the openendedness of new faith expressions in which the apostolic faith are set forth today. If American (Horgan 1988) and German (Staats 1996:305) Christians explain the uniqueness

6. See my discussion of the how to deal theologically with so-called "non-theological" factors in an ecumenical situation (Naude 1999).

7. One in any case wonders whether $\mathrm{NC}$ would have engendered such great interpretative interest if it were not for the filioque question - that is actually the only outstanding "issue" for the older churches to resolve today. See Oberdorfer (2000:129ff) for an elaborate history of the filioque problem. 
of their respective ecclesial contexts and how difficult it is to implement the NC-project, an African statement is even more appropriate.

\subsection{What influence did the Nicea process itself have?}

One could raise the ethical question related to the cost of 300 theologians involved in 18 conferences all over the globe to produce a document of 130 odd pages. One could ask whether the whole project is not a form of "ecumenism from above" driven by professional ecumenical theologians with very little resonance in grassroots Christian communities themselves. I would, however, rather accept the limitations of the ecumenical process and pursue the question of a "missed opportunity":

I refer here to the process of "Giving account of the hope that is in us" which commenced with the Faith and Order-conference in Louvain in 1971. The "common expression of our faith" was here linked to "giving account of our hope" and not to a formulation of a confession: "The study will not aim at the formulation of a creed or confession; it will rather be an effort to give account of our faith today" (Faith and Order Paper 59:239). This led to a magnificent array of witnesses published in the wellknown volumes by Choan-Seng Song Giving account of our hope today (FO paper 81, Geneva 1976) and Giving account of our hope together (FO paper 86, Geneva 1978).

The difficulty to find a common point of reference ${ }^{8}$ in such a multitude of witnesses on the one hand, and the relative success of a common statement on BEM on the other, led to a historicizing countermovement. And it (un?)intentionally started from a kind of principium qiunquesaecularis of a pristine and undivided church, easily forgetting the political and theological strife subsumed under common formulations from the early church (Brinkmann 1996:61, 62). The choice was clearly for a historical confession instead of an openness to confess the faith anew in different contexts and with different images that could subsequently have been tested as to their 'consenus catholicus'.

\subsection{How does Nicea relate to the basic apostolic faith?}

Despite the express intention of the study guide Towards sharing the one faith that "the point of the text is not the Nicene Creed itself but engagement with the basic issues of the Christian apostolic faith" (Falconer 1998:179), the whole project in practice condense the apostolic faith to the NC and accord this creed unparalleled status.

The very concept "apostolic faith" has a variety of meanings in the context of the WCC. George vanderVelde (1988) points to six such aspects including unity of apostolic faith which exists "...in the pluriformity of Christian traditions in a great diversity of contexts" (point 4). It is, however, interesting to note that before the Scriptures as fundamental criterion (norma normans) is mentioned in point 6, VanderVelde notes that "apostolic faith" is linked by the WCC to the NC “...as the ecumenical symbol par excellence" (point 5). This is understandable for the historical reasons mentioned above, but there are formulations in Confessing the one faith that point to NC itself being a criterion for other, modern expressions of the apostolic faith, e.g.: "The Nicene Creed thus serves to indicate whether the faith as set forth in modern situations is the same faith as the one the church confessed through the centuries" (par 12, my emphasis; see also par 16). This suggests a canonizing function that is normally assigned to Scripture alone (Brinkmann 1996:72-73)

8. Is this search for a common denominator a kind of modernist urge for ecclesial control, or perhaps a lack of trust in whither the wind blows? 
and represents a narrowing down of the apostolic faith so eloquently expressed in Van der Velde's fourth point quoted above.

Neuner reckons that this "Rückbesinnung auf die fruehe Kirche, ihre Ordnung und Lehrentscheidungen" can be explained from both the method adopted for the confessing project and ecumenical politics at Lima: "Es ist offentsichtlich, dass sich hier die orthodoxen Tradition, die in Lima stark repraesentiert war, durchsetzen konnte. Fuer the Orthodoxe ist es unabweislich, dass eine Einigung nur auf der Basis der fruehen Kirche erfolgen kann" (Neuner 1997:165 and Brinkmann's note on the "historicizing approach" of the Eastern church, 1996:73-74).

\subsection{How should we interpret the concept of ecumenism today?}

I have, up to now, remained within the paradigm of the ecumenical movement as represented by the WCC and Faith and Order. The danger exists, however, that the very concept of "ecumenism" could be restricted to its inner-ecclesial meaning of "relationships among churches belonging to the WCC".

Etymologically speaking, we all know that oikumene refers to the "inhabited earth" initially understood to be the Roman empire. After the fall of this empire, oikumene acquired a "churchly" meaning with reference to the universal, i.e. ecumenical councils. In the 20th century the reference to the ecumenical movement again shifted the meaning to efforts of church unity later represented by the WCC. But as early as 1951, in the so-called Toronto-declaration, the WCC itself declared that the term "ecumenical" be used as expression of the whole work of the whole church in the proclamation of the gospel in the whole world. The unity of the church is not an aim in itself, but directed at testimony and service to the world (see Frieling 1992:6).

If this "outward-looking" understanding of oikumene is regained, it opens the way for a different paradigm of ecumenism. Wolfgang Huber develops this idea by observing that we have reached a point in history where the experience of one world (oikumene!) is a reality. But this reality is filled with paradoxes and the knowledge of huge discrepancies. The search for unity therefore is fundamentally ethical, directed "...zu einem vorrangige Kriterium fuer eine christliche Praxis, die sich an der Aufgabe orientiert, fuer die Ueberwindung dieser Widersprueche zu arbeiten und zu kampfen" (Huber 1980:48). Apart from an ethical unity, ecumenical theology's dialogical nature should be extended from inner-Christian confessional dialogues, to an ecumenism of religions and nations (1980:71) to truly include "the world" as ethically one world".

Huber does not - as far as I could gather - work out the implications of an ethical ecumenism for our understanding of the apostolic faith. The apostolic faith is without doubt carried forth in the church through normative common creeds and confessions. In Episcopal churches the magisterial epsicopacy functions as normative teaching office to guard and set the apostolic faith forth. But is it not also valid to claim that discipleship of Jesus Christ and following Him in acts of love, justice and peace in solidarity with the poor and marginalised is an equally normative expression of the apostolic faith? A holy and liberating life is - according to the Scriptures - at the heart of prophetic and apostolic fidelity (see Horgan 1988:65).

Without in any way devaluing the $\mathrm{NC}$ or any other creed, it must be clear that, in the light of HIV/Aids, the unfinished project of reconciliation; radical and growing poverty;

9. See also the effort of a paradigm switch by Konrad Raiser (1989), and Christoff Schwoebel's discussion from a trinitarian perspective (Schwoebel 1997:322ff ). 
signs of moral disorientation and anomie in a society in transition (see Durkheim 1963:252253); the churches in SA today will follow Jesus Christ better by an authentic ecumenical praxis, than by a careful and drawn-out explication of the creeds. This is no antidogmatism or a non-creedal view; it is a judgement of our present situation where a specific choice is made for a specific mode of the apostolic faith (normative praxis) without loosing sight of other modes (normative creeds and confessions) that inevitably inform and are informed by our praxis.

\subsection{Is Nicea helpful in the urgent task to re-establish the public role of theology in SA?}

In the context of the so-called "public theology"- debate in the USA, Cady focuses on three issues: Which publics are addressed? How are they addressed, i.e. what mode of presentation is appropriate? And are timely issues adequately addressed? (see Cady 1987). Let us examine the Confessing the one faith-project from this perspective:

\section{Which publics?}

It seems obvious that the only public that will be served by such a project is the church itself. Contrary to the original context where $\mathrm{NC}$ and other later creeds and confessions assumed huge public and specific political importance far beyond the boundaries of the church, an explication of NC today will at most serve the awareness of active church members (which is obviously not to be discarded). Such a process might also gain some prominence in the public of the academia, but then probably confined to theology that is in our context not really an alternative public to the church.

\section{What mode?}

It is highly unlikely that a text designed for both restraining heresies in the fourth century and a credal-liturgical expression, is in its "format" appropriate for witnessing to a society such as ours. A fruitful engagement with different publics in an open, democratic sphere requires different modes of communication ranging from lobbying legislation to networking with NGO's and writing letters to the newspaper. In a country where some of the church -groupings are about the last social structures to still become one, the world is not waiting with huge expectation for a delayed unity which in itself would have been a mode of witnessing to true reconciliation in Christ. Even within the church, very few ordinary members will naturally be excited by the language of Nicea - especially where the creed is "on the books" in Reformed churches, but rarely liturgically used. (This might change through repeated use though).

\section{Which timely issues?}

Nicea has - like any ancient text - obvious potential for an interpretation that takes contemporary issues into account. My contention is that the filioque is not one of them (as it appears with only one cursory reference in par 210 of Confessing the one faith!). The Confessing study is nevertheless a limited sign of such interpretation. Limited, because it is apparent that the primary context to which the interpretation is aimed, is a Western, modern, secular society under ecological threat (par 84-89, 205, 258, 270, 276) and where the core polemical issue is the acceptance of a reality beyond the physical world which allows for faith in a transcendent God (see par 7, 21, 23, 28 and Hebblethwaite 1996:68).

The interpretation is not only limited in scope, but also in its judging of an issue such as gender sensitive readings of the bible - and this from an almost fundamentalist, a-historical perspective: "We may not surrender the language of 'Father' for it is the way in which 
Jesus addressed, and spoke of, God and how Jesus taught his disciples to address God... The language of 'Father' and 'Son' links the Christian community through the ages and binds it in a communion of faith. Moreover, it is the language which expresses the personal relationships within the inner life of the Trinity, and in our relations with God " (par 50, despite a statement on language as approximate description of God in par 49!).

One could obviously write an explication on "reading the Nicene creed in South Africa today". But once completed, and with the construction of a public theology in mind, what do you do with it? It is from my perspective doubtful that such interpretation will move beyond the circle of professional theologians into the public sphere. And even the theologians might ask: Why not rather address the timely issues (as is expected from any good public theology) directly from Scripture with its rich variety of themes and perspectives, and obvious advantage of both canonical status in the church and relative knowledge by the public at large?

\section{Conclusion}

No one from the creedal churches would argue against the retention of $\mathrm{NC}$ as part of our rich heritage of witnesses to the apostolic faith. Very few from (South) Africa, I think, will argue that its common explication - the starting point of the WCC-project - is the most urgent witness of the church to that common, apostolic faith. Even fewer will propose its explication as credible service to the world today.

The apostolic faith in SA today is not carried forth primarily through prophetic witness - rather through quite, dedicated priestly service (Rom 12:1-2; Heb 13). Pure and genuine religion before God is to take care of orphans and widows in their suffering (James 1:27).

This is whither the wind blows. Softly, sometimes incognito (Matt 25), but nevertheless authentic. 


\section{BIBLIOGRAPHY}

Arens, Edmund 1989. Bezeugen und Bekennen. Elementare Handlung des Glaubens. Patmos: Dusseldorf.

Brinkmann, Martien E 1996. Progress in unity? Fifty years of theolgoy within the WCC: 19451995. Peters Press: Louvain.

Cady, LE 1987. A model for public theology. The Harvard Theological Review, 80, 193-212.

Confessing the one faith (revised edition) 1991. Faith and Order Paper no 153. WCC: Geneva.

Durkheim, Emile 1963 (1897) Suicide. A study in Sociology. The Free Press: Glencoe.

Falconer, Alan 1998. Faith and Order in Moshi. The 1996 Commission meeting. Faith and Order Paper no 177. WCC: Geneva.

Gassmann, Guenther 1993. Documentary history of Faith and Order 1963-1993. WCC: Geneva.

Frieling R 1992. Der Weg des oekumenischen Gedankens. Eine Oekumenekunde. Vandenhoeck \& Ruprecht: Goettingen.

Harakas SS 1991. "Must God remain Greek?” The Ecumenical Review 43, 194-199.

Hebblethwaite, Brian 1996. The essence of Christianity: A fresh look at the Nicene creed. SPCK: London.

Hendriks, Jurgens H 1995. South African denominational growth and decline 1911-1991. JTSA, 91:35-58.

Hood, Robert 1990. Must God remain Greek? Afro-cultures and God-talk. Minneapolis.

Horgan, Thadeleus D (ed) 1988. Apostolic faith in America. Eerdmans: Grand Rapids.

Huber, Wolfgang 1980. Die Streit um die Wahrheit und die Faehigkeit zum Frienden. Vier Kapitel oekumenische Theologie. München.

Kelly, JDN 1972. Early Christian creeds ( $3^{\text {rd }}$ edition). Longman: London.

Link. Hans-George 1998. Bekennen und Bekenntnis. Vandenhoeck \& Ruprecht: Goettingen.

Naude, Piet 1999. How do we deal theologically with so called non-theological factors? Paper delivered at the second Princeton Theological Seminary conference on Reformed identity and ecumenicity, Heidelberg, Germany (forthcoming proceedings 2001).

Neuner, Peter 1997. Oekumenische Theologie. Die Suche nach der Einheit der christlichen Kirche. Wissenschaftliche Buchgesellschaft: Darmstadt.

Oberdorfer, Bernd 2000. Filioque. Geschichte und Theologie eines oekumenischen Problems. Vandenhoeck \& Ruprecht: Goettingen.

Raiser, Konrad 1989. Oekumene im Uebergang: Paradigmenwechsel in der Oekumenischen Bewegung. München.

Schwoebel. Christoff 1997. Oekumenische Theologie im Horizont des trinitarischen Glaubens. Oekumenische Rundschau 46, 321-340.

Sieben, Hermann Josef 1979. Die Konzilsidee der alten Kirche. Ferdinand Schoeningh: Paderborn.

Song, Choan-Seng 1976. Giving account of our hope today. FO Paper 81. WCC: Geneva.

Song, Choan-Seng 1978. Giving account of our hope together. FO Paper 86. WCC: Geneva.

Staats, Reinhart 1996. Das Glaubensbekenntinis von Nizaea-Konstantinopel. Historische und theologische Grundlagen. Wissenschaftliche Buchgesellscahft: Darmstadt.

Vandervelde, George 1988. The meaning of "apostolic faith": in World Council of Church's documents, in Horgan (ed), 20-25.

Towards sharing the one faith 1996. Faith and Order Paper no 173. WCC: Geneva.

Towards the common expression of the apostolic faith. WCC: Geneva.

WCC Constitution, Rules, Regulations and By-laws 1996. WCC: Geneva . 